\title{
Penentuan Kelas Menggunakan Algoritma K Medoids Untuk Clustering Siswa Tunagrahita
}

\author{
Husin Sariangsah*, Wanayumini, Rika Rosnelly \\ Fakultas Teknik dan Ilmu komputer, Program Studi Magister Ilmu Komputer, Universitas Potensi Utama, Medan, Indonesia \\ Email: 1," husinsariangsah1@gmail.com, ${ }^{2}$ wanayumini@gmail.com, ${ }^{3}$ rikarosnelly@ gmail.com \\ Email Penulis Korespondensi: husinsariangsah1@gmail.com
}

\begin{abstract}
Abstrak-Selama ini penempatan kelas siswa tunagrahita bersumber pada umur masuk anak dikala mendaftar di SLB C Muzdalifah, tidak dicoba uji Intelligence Quotient (IQ) buat siswa tunagrahita dalam mengelompokkan kelas siswa. Pengelompokkan anak tunagrahita penting dilakukan untuk mempermudah guru dalam menyusun program dan melaksanakan layanan pendidikan. Penting bagi pihak sekolah untuk memahami bahwa pada anak tunagrahita terdapat perbedaan individual yang variasinya sangat besar. Artinya, berada pada level usia (usia kalender dan usia mental) yang hampir sama serta jenjang pendidikan yang sama, kenyataannya kemampuan individu berbeda satu dengan lainnya. Dengan demikian, sudah barang tentu diperlukan strategi dan program khusus yang disesuaikan dengan perbedaan individual. Penelitian ini dibuat untuk mengelompokkan dan analisis data mining untuk clustering kelas siswa dengan algoritma $K$ Medoids dapat menolong dalam pengelompokkan siswa yang hendak menempati kelas sesuai tingkat ketunagrahitaannya. Dari hasil pengelompokan didapat 3 cluster, yang memiliki jumlah siswa paling tinggi ialah kelas tunagrahita sedang dan cluster yang rendah ialah tunagrahita ringan, pihak sekolah luar biasa Muzdalifah dapat mempersiapkan kelas berdasarkan pengelompokan untuk aktivitas belajar mengajar.
\end{abstract}

Kata Kunci: Clustering; K-Medoids; Tunagrahita

\begin{abstract}
So far, the class placement of mentally retarded students is based on the age of entering the child when registering at SLB C Muzdalifah, the Intelligence Quotient (IQ) test has not been tried for mentally retarded students in classifying student classes. It is important to group mentally retarded children to make it easier for teachers to prepare programs and implement educational services. It is important for the school to understand that in mentally retarded children there are individual differences with very large variations. That is, being at almost the same age level (calendar age and mental age) and the same education level, in fact individual abilities differ from one another. Thus, of course, special strategies and programs are needed that are adapted to individual differences. This research was made to classify and analyze data mining for class clustering students with the K-Medoids algorithm to help group students who want to occupy classes according to their level of intellectual disability. From the grouping results obtained 3 clusters, which have the highest number of students is the moderate mental retardation class and the lowest cluster is mild mental retardation, the Muzdalifah special school can prepare classes based on grouping for teaching and learning activities.
\end{abstract}

Keywords: Clustering; K-Medoids; Mentally Disabled

\section{PENDAHULUAN}

SLB C Muzdalifah ialah sekolah yang melayani anak berkebutuhan khusus yang memberikan fasilitas pembelajaran untuk anak berkebutuhan istimewa. Anak Berkebutuhan Spesial (ABK) mempunyai hak yang sama buat dapat bersekolah di sekolah universal, perihal ini sudah diatur dalam peraturan perundangan No: 20 tahun 2003. SLB Muzdalifah yang terletak pada jalan Garu VI gg. Merak Nomor 15 Medan tidak hanya memberi pendidikan untuk anak tunagrahita tetapi anak dengan tunarungu juga dapat pelayanan pendidikan disekolah tersebut. Sepanjang ini penempatan kelas buat siswa tunagrahita bersumber pada umur masuk anak pada saat mendaftar di SLB C Muzdalifah, tidak dicoba uji Intelligence Quotient(IQ) buat siswa tunagrahita dalam mengelompokkan kelas siswa. Sehingga menyebabkan proses belajar mengajar sedikit tersendat. Karena anak tunagrahita mempunyai penanganan yang berbeda beda sesuai dengan keahlian orang tiap- tiap.

Untuk mempermudah pihak sekolah dalam menetukan kelas siswa berdasarkan ketunagrahitaannya dibutuhkan metode clustering. Dimana siswa dikelompokkan berdasarkan kemampuannya berdasarkan variabel penilaian yang telah dilakukan guru. Sehingga terbentuklah cluster dimana siswa memiliki kesamaan berada pada cluster yang sama[1]. Dalam data mining metode $k$-means merupakan algoritma yang berperan dalam clustering. Pengembangan k-means clustering yaitu k-medoids bertujuan mengurangi sensitivitas dari partisi yang dihasilkan sehubungan dengan nilai-nilai ekstrim yang terdapat didalam dataset. Algoritma k-medoids muncul untuk menanggulangi kelemahan k-means yang sensitif terhadap outliner.

Pada penelitian sebelumnya[2] menggunakan teknik clustering dengan menggunakan algoritma $k$ medoids dalam melakukan pemasaran produk. Hasil yang didapatkan pemasaran produk lebih efektif dan efisien. Data yang didapat diolah untuk mengetahui pola sehingga diperoleh informasi yang tersembunyi.

Pada Penelitian yang lain [3] menggunakan algoritma k-medoids sehingga lebih cepat mengetahui penyebaran anak cacat di wilayah tertentu. Banyak nya anak cacat didaerah riau yang masih kurang ditangani sehingga diperlukan sistem untuk pengetahui penyebaran anak cacat agar dapat penanganan secara dini.

Berdasarkan latar belakang masalah dan pemaparan penelitian terdahulu, penulis membuat penelitian untuk menganalisa kelas siswa tunagrahita dengan menerapkan data mining clustering menggunakan algoritma $k$-medoids, dimana variabel yang digunakan yaitu nilai akademik, nilai kepribadian, nilai kemandirian, nilai 
berpikir verbal dan kecakapan/ketelitian. Hasil yang didapat terbentuk 3 cluster berdasarkan ketunagrahitaan siswa sesuai dengan pengelompokkan yang digunakan di Indonesia saat ini yaitu tunagrahita ringan, sedang dan berat. Algoritma K-Medoids ini membantu dengan cepat mengetahui pengelompokkan siswa, sehingga pihak sekolah dapat menyiapkan sarana dan prasarana sesuai dengan kemampuan individu siswa.

\section{METODE PENELITIAN}

\subsection{Kerangka Kerja Penelitian}

Kerangka kerja penelitian yang dibuat secara sistematis yang mengarah pada tahapan proses yang akan ditempuh pada penelitian ini dapat dilihat pada gambar 1 .

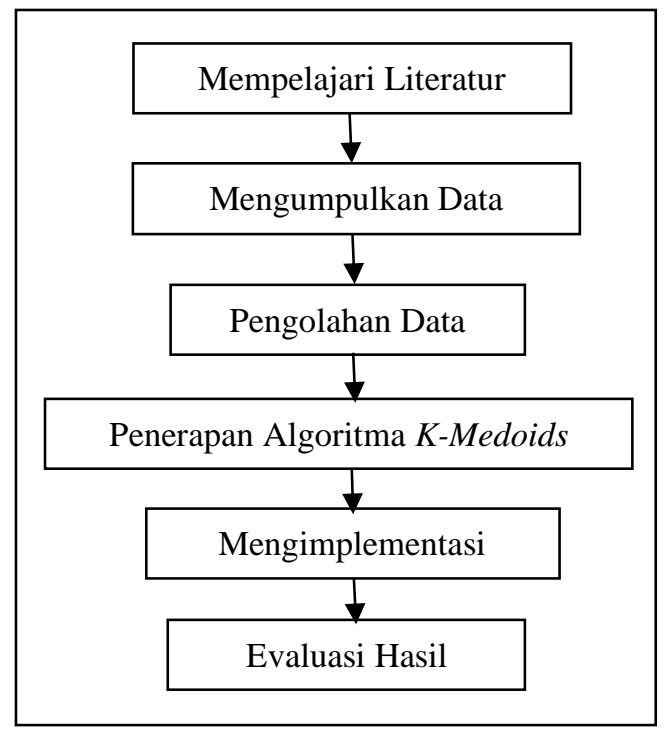

1. Mempelajari Literatur

Gambar 1. Kerangka Penelitian

Mempelajari literatur yang bersumberkan dari buku-buku, jurnal yang berhubungan dengan penelitian.

2. Mengumpulkan Data

Peneliti mengamati dan mengumpulkan informasi dari sekolah luar biasa Muzdalifah. Melakukan wawancara langsung kepada guru yang berhubungan dengan proses dalam penentuan kelas siswa yang berlangsung selama ini dengan mengajukan pertanyaan diantaranya;

a. Bagaimana proses penentuan kelas tunagrahita yang selama ini dilakukan?

b. Apakah dalam penentuan kelas tunagrahita menggunakan aturan tertentu yang diberlakukan oleh sekolah?

c. Kendala apa saja yang biasa dialami oleh para guru kelas saat membawakan matapelajaran di kelas Tunagrahita?

3. Pengolahan Data

Penulis melakukan penglolahan informasi dini yang telah dibuat dan dipergunakan untuk diolah. Variabel yang jadi nilai penentu kelas tunagrahita diolah menggunakan algoritma k-medoids.

4. Penerapan Algoritma $K$ - Medoids

Pada penerapan Algoritma, dilakukan perhitungan manual dengan menggunakan data yang didapat dari sekolah luar biasa Muzdalifah. Variabel yang digunakan nilai akademik, nilai kepribadian, nilai kemandirian, nilai berpikir verbal dan kecakapan/ketelitian.

5. Mengimplementasi

Tahap selanjutnya menyusaikan dengan pengolahan informasi hingga pada sesi implementasi merupakan tentang bagaimana pengolahan informasinya diterapkan dalam suatu tools.

6. Evaluasi

Melakukan evaluasi terhadap informasi yang ditemukan apakah sesuai dengan realita terdahulu.

\subsection{Data Mining}

Data mining adalah proses yang menggunakan teknik statistik, matematika, kecerdasan buatan, dan machine learning untuk mengekstraksi dan mengidentifikasi informasi yang bermanfaat dan pengetahuan yang terkait dari berbagai database besar. Salah satu teknik yang ada pada data mining adalah klasifikasi [4],[5],[6].

Data mining adalah proses analitik yang dirancang untuk memeriksa sejumlah data yang besar dalam mencari suatu pengetahuan tersembunyi yang berharga dan konsisten. Tujuan dari data mining yaitu mencari trend atau 
pola yang diinginkan dalam database besar untuk membantu dalam pengambilan keputusan pada waktu yang akan datang [7],[8],[9],[10].

\subsection{Tunagrahita}

Anak tunagrahita adalah individu yang secara signifikan memiliki intelegensi dibawah intelegensi normal. Menurut American Association on Mental Deficiency mendefinisikan Tunagrahita sebagai suatu kelainan yang fungsi intelektual umumnya di bawah rata- rata, yaitu IQ 84 ke bawah [11].

Pengklasifikasian anak tunagrahita penting dilakukan untuk mempermudah guru dalam menyusun program dan melaksanakan layanan pendidikan. Klasifikasi yang digunakan di Indonesia saat ini sesuai dengan PP 72 Tahun 1991 adalah sebagai berikut[12] :

1. Tunagrahita ringan IQ-nya 50 - 70,

2. Tunagrahita sedang IQ-nya $30-50$,

3. Tunagrahita berat dan sangat berat IQ-nya kurang dari 30.

\subsection{Algoritma K-Medoids}

Teknik clustering k-medoids merupakan pengembangan dari k-means. Algoritma k-medoids menutupi kelemahan k-means. Kedua algoritma tersebut sama-sama algoritma clustering dimana k-medoids menggunakan nilai perwakilan medoids untuk setiap kelompok[13][14][15].

Langkah-langkah Algoritma K-Medoids[16] :

1. Inisialisasikan pusat cluster sebanyak jumlah cluster $(\mathrm{k})$

2. Setiap data dialokasikan ke cluster menggunakan persamaan ukuran Euclidian Distance dengan rumus 2.1 :

$$
(\mathrm{x}, \mathrm{y})=\sqrt{\sum_{i=1}^{n}\left(x_{i}-y_{i}\right)^{2}}
$$

Dimana:

$\mathrm{d}(\mathrm{x}, \mathrm{y})=$ jarak antara data ke-i dan data ke-j

xi1 = nilai atribut ke satu dari data ke-i

yj1 = nilai atribut ke satu dari data ke-j

$\mathrm{n}=$ jumlah atribut yang digunakan

3. Pilih objek pada masing-masing cluster secara acak sebagai medoid yang baru.

4. Hitung jarak setiap objek yang terdapat pada masing-masing

5. Hitung total simpangan (S) dengan menghitung nilai total jarak baru- total jarak lama. Jika didapatkan $S<0$, tukarkan objek dengan data cluster untuk membuat medoid yang baru.

6. Ulangi langkah 3 sampai 5 hingga didapatkan cluster beserta anggota cluster masing-masing.

\section{HASIL DAN PEMBAHASAN}

\subsection{Pengolahan Data}

Riset ini dilaksanakan memakai informasi nilai dari Sekolah Luar Biasa C Muzdalifah Medan. Nilai tersebut hendak dijadikan dasar dalam penentuan kelas tunagrahita. Data nilai yang digunakan yaitu nilai akademik, nilai kepribadian, nilai kemandirian, nilai berpikir verbal dan kecakapan/ketelitian. Data Nilai tersebut diperoleh dari penilaian guru kelas pada 6 bulan pertama awal pembelajaran. Data nilai tersebut digunakan dalam perhitungan manual dengan algoritma K-medois dan diimplementasikan dengan tools Rapid Miner.

Tabel 1. Data Nilai Awal

\begin{tabular}{clccccc}
\hline No & Nama & N_Akademik & N_Kepribadian & N_kemandirian & N_Vebal & N_Kecakapan \\
\hline 1 & M. Akbar Nst & 68 & 70 & 70 & 70 & 70 \\
2 & Nurul asha Br. Sinaga & 70 & 71 & 72 & 70 & 73 \\
3 & Randi Alvino & 68 & 69 & 68 & 66 & 69 \\
4 & Syifa Amima & 68 & 69 & 69 & 69 & 70 \\
5 & Muhammad Ilham & 68 & 68 & 67 & 67 & 70 \\
6 & Fazrina kanaya & 65 & 65 & 66 & 65 & 67 \\
7 & Hanip Hasan & 75 & 74 & 75 & 76 & 76 \\
8 & Lidya Anggrainy & 72 & 72 & 73 & 72 & 75 \\
9 & Luthfi Rahman Husin & 69 & 70 & 70 & 70 & 71 \\
10 & M. Rizky Pranata & 68 & 68 & 65 & 66 & 71 \\
11 & Ramadan & 75 & 73 & 75 & 75 & 76 \\
12 & Rizky Ramadan & 72 & 65 & 71 & 70 & 74 \\
13 & Aditya & 70 & 75 & 80 & 80 & 78 \\
14 & Inayah Rizkiyah Natama & 74 & 73 & 79 & 70 & 73 \\
15 & Hrp & 60 & 63 & & & 62 \\
\hline
\end{tabular}


JURNAL MEDIA INFORMATIKA BUDIDARMA

Volume 5, Nomor 1, Januari 2021, Page 83-89

ISSN 2614-5278 (media cetak), ISSN 2548-8368 (media online)

Available Online at https://ejurnal.stmik-budidarma.ac.id/index.php/mib DOI 10.30865/mib.v5i1.2547

\begin{tabular}{|c|c|c|c|c|c|c|}
\hline 16 & $\begin{array}{l}\text { Miftahul dina Qoyyima } \\
\text { Butar butar }\end{array}$ & 71 & 64 & 73 & 65 & 70 \\
\hline 17 & Rasyifa Musyarahmi & 80 & 78 & 80 & 80 & 80 \\
\hline 18 & Rizky Mulia Siregar & 65 & 62 & 65 & 65 & 67 \\
\hline 19 & Wakai Alfauzan & 79 & 73 & 80 & 70 & 78 \\
\hline 20 & $\begin{array}{l}\text { Amando Yakub } \\
\text { parlindungan }\end{array}$ & 70 & 70 & 79 & 70 & 73 \\
\hline 21 & M. Eriko & 68 & 62 & 63 & 63 & 65 \\
\hline 22 & Ramadhan Ichsan & 68 & 63 & 62 & 63 & 63 \\
\hline 23 & Annisa & 80 & 78 & 78 & 78 & 85 \\
\hline 24 & Mhd. Adly faturrahman & 85 & 85 & 85 & 87 & 89 \\
\hline 25 & Ririn Qurata 'Ayyum & 60 & 60 & 60 & 60 & 60 \\
\hline 26 & Suci rahmadani & 70 & 70 & 75 & 70 & 75 \\
\hline 27 & Alvin Aditya & 75 & 80 & 78 & 75 & 85 \\
\hline
\end{tabular}

\subsection{Penerapan Algoritma K-Medoids Clustering}

Urutan proses penerapan algoritma yaitu:

a. Inisialisasi sebanyak 3 cluster berdasarkan klasifikasi anak tunagrahitadi Indonesia. Dari data sampe setiap medoid dipilih secara acak diasumsikan Alvin Aditya, Suci rahmadani dan Ririn Qurata 'Ayyum sebagai medoid awalseperti terdapat pada tabel 2 :

Tabel 2. Medoid Awal

\begin{tabular}{lccccc}
\hline Nama & N_Akademik & N_Kepribadian & N_kemandirian & N_Vebal & N_Kecakapan \\
\hline Alvin Aditya & 75 & 80 & 78 & 75 & 85 \\
Suci rahmadani & 70 & 70 & 75 & 70 & 75 \\
Ririn Qurata 'Ayyum & 60 & 60 & 60 & 60 & 60 \\
\hline
\end{tabular}

b. Perhitungan jarak Euclian Distance menggunakan medoid awal sebagai berikut :

$\mathrm{D}(\mathrm{M} . \mathrm{Akbar} \mathrm{Nst})=\sqrt{\left((68-75)^{2}+(70-80)^{2}+(70-78)^{2}+(70-75)^{2}+(70-85)^{2}\right)}$

$=\mathbf{2 1 , 5 1 7 4}$

$\mathrm{D}(\mathrm{M}$. Akbar Nst $)=\sqrt{\left((68-70)^{2}+(70-70)^{2}+(70-75)^{2}+(70-70)^{2}+(70-75)^{2}\right)}$

$=7,3485$

$\mathrm{D}(\mathrm{M} . \mathrm{Akbar} \mathrm{Nst})=\sqrt{\left((68-60)^{2}+(70-60)^{2}+(70-60)^{2}+(70-60)^{2}+(70-60)^{2}\right)}$

$=\mathbf{2 1 , 5 4 0 7}$

Perhitungan diatas merupakan sampel data M.Akbar Nst untuk mendapatkan nilai C1,C2 dan C3 menggunakan medoid awal. Perhitungan nilai cost seluruhnya seperti tabel 3 berikut :

Tabel 3. Data keseluruhan Iterasi ke-1

\begin{tabular}{|c|c|c|c|c|c|c|}
\hline \multirow[t]{2}{*}{ No } & \multirow[t]{2}{*}{ Nama } & \multicolumn{3}{|c|}{ Jarak Ke Medoids } & \multirow{2}{*}{$\begin{array}{c}\text { Jarak } \\
\text { Terdekat }\end{array}$} & \multirow{2}{*}{$\begin{array}{c}\text { Cluster yang } \\
\text { di Ikuti }\end{array}$} \\
\hline & & C1 & $\mathrm{C} 2$ & C3 & & \\
\hline 1 & M. Akbar Nst & 21,5174 & 7,3485 & 21,5407 & 7,3485 & 2 \\
\hline 2 & Nurul asha Br. Sinaga & 17,6352 & 3,7417 & 25,1794 & 3,7417 & 2 \\
\hline 3 & Randi Alvino & 24,6374 & 10,2956 & 18,0555 & 10,2956 & 2 \\
\hline 4 & Syifa Amima & 22,6274 & 8,1854 & 20,1742 & 8,1854 & 2 \\
\hline 5 & Muhammad Ilham & 24,5561 & 10,2956 & 18,0555 & 10,2956 & 2 \\
\hline 6 & Fazrina kanaya & 29,8831 & 14,8324 & 12,6491 & 12,6491 & 3 \\
\hline 7 & Hanip Hasan & 11,2694 & 8,8318 & 34,0294 & 8,8318 & 2 \\
\hline 8 & Lidya Anggrainy & 14,3875 & 4,0000 & 28,7402 & 4,0000 & 2 \\
\hline 9 & Luthfi Rahman Husin & 20,5183 & 6,4807 & 22,4054 & 6,4807 & 2 \\
\hline 10 & M. Rizky Pranata & 25,2784 & 11,8322 & 17,6068 & 11,8322 & 2 \\
\hline 11 & Ramadan & 11,7898 & 7,7460 & 33,1662 & 7,7460 & 2 \\
\hline 12 & Rizky Ramadan & 20,7123 & 6,7823 & 24,2074 & 6,7823 & 2 \\
\hline 13 & Aditya & 11,3137 & 12,6095 & 38,0657 & 11,3137 & 1 \\
\hline 14 & $\begin{array}{l}\text { Inayah Rizkiyah Natama } \\
\text { Hrp }\end{array}$ & 14,8324 & 6,7082 & 31,5436 & 6,7082 & 2 \\
\hline 15 & Jumadil & 35,0428 & 19,4679 & 11,3578 & 11,3578 & 3 \\
\hline 16 & $\begin{array}{l}\text { Miftahul dina Qoyyima } \\
\text { Butar butar }\end{array}$ & 24,9399 & 9,5394 & 20,7605 & 9,5394 & 2 \\
\hline 17 & Rasyifa Musyarahmi & 9,1104 & 17,7200 & 43,8634 & 9,1104 & 1 \\
\hline 18 & Rizky Mulia Siregar & 31,8904 & 16,6733 & 11,3137 & 11,3137 & 3 \\
\hline 19 & Wakai Alfauzan & 11,9583 & 11,1355 & 36,7967 & 11,1355 & 1 \\
\hline 20 & $\begin{array}{l}\text { Amando Yakub } \\
\text { parlindungan }\end{array}$ & 17,1756 & 4,4721 & 28,8097 & 4,4721 & 2 \\
\hline
\end{tabular}


JURNAL MEDIA INFORMATIKA BUDIDARMA

Volume 5, Nomor 1, Januari 2021, Page 83-89

ISSN 2614-5278 (media cetak), ISSN 2548-8368 (media online)

Available Online at https://ejurnal.stmik-budidarma.ac.id/index.php/mib DOI 10.30865/mib.v5i1.2547

\begin{tabular}{|c|c|c|c|c|c|c|}
\hline 21 & M. Eriko & 33,7935 & 19,0000 & 10,5357 & 10,5357 & 3 \\
\hline 22 & Ramadhan Ichsan & 34,9571 & 20,3715 & 9,7468 & 9,7468 & 3 \\
\hline 23 & Annisa & 6,1644 & 18,3576 & 44,6878 & 6,1644 & 1 \\
\hline 24 & Mhd. Adly faturrahman & 18,2757 & 32,1714 & 58,6941 & 18,2757 & 1 \\
\hline 25 & Ririn Qurata 'Ayyum & 42,4146 & 27,3861 & 0,0000 & 0,0000 & 3 \\
\hline 26 & Suci rahmadani & 16,0935 & 0,0000 & 27,3861 & 0,0000 & 2 \\
\hline \multirow[t]{3}{*}{27} & Alvin Aditya & 0,0000 & 16,0935 & 42,4146 & 0,0000 & 1 \\
\hline & Jumlah & $\mathbf{5 5 2 , 7 7 4 7}$ & 332,0783 & 691,7862 & & \\
\hline & Total Cost & & 1576,6392 & & & \\
\hline
\end{tabular}

Berdasarkan tabel 3 diatas didapatkan total cost $=\mathbf{1 5 7 6 , 6 3 9 2}$, total cost tersebut diperoleh dengan menjumlahkan ketiga jumlah $\mathrm{C} 1, \mathrm{C} 2$ dan $\mathrm{C} 3$. Menentukan jarak terdekat dengan pusat cluster data dapat menggunakan rumus MIN (Cij; Ckj). Adapun hasil penentuan jarak terdekatk terhadap pusat cluster yang telah ditabulasikan pada tabel 3. Kemudian dilakukan perhitungan iterasi kedua sesuai langkah-langkah algoritma $k$ medoids untuk menghitung total simpangan $(\mathrm{S})$ dengan menghitung nilai total jarak baru- total jarak lama. Hasil total cost yang didapat diatas merupakan totak jarak lama. Perhitungan Iterasi kedua menggunakan kandidat medoid yang baru dipilih secara acak seperti tabel 4 berikut :

Tabel 4. Medoid Baru Iterasi ke-2

\begin{tabular}{lccccc}
\hline Nama & N_Akademik & N_Kepribadian & N_kemandirian & N_Vebal & N_Kecakapan \\
\hline Mhd. Adly faturrahman & 85 & 85 & 85 & 87 & 89 \\
Lidya Anggrainy & 72 & 72 & 73 & 72 & 75 \\
Fazrina kanaya & 65 & 65 & 66 & 65 & 67 \\
\hline
\end{tabular}

Perhitungan dilakukan ulang untuk mendapatkan iterasi kedua menggunakan medoid baru untuk C1, C2 dan C3.

$$
\begin{aligned}
& \text { D }(\text { M.Akbar Nst })=\sqrt{\left((68-85)^{2}+(70-85)^{2}+(70-85)^{2}+(70-87)^{2}+(70-89)^{2}\right)} \\
& =\mathbf{3 7 , 2 6 9 3} \\
& \text { D }(\text { M.Akbar Nst })=\sqrt{\left((68-72)^{2}+(70-72)^{2}+(70-73)^{2}+(70-72)^{2}+(70-75)^{2}\right)} \\
& =\mathbf{7 , 6 1 5 8} \\
& \text { D }(\text { M.Akbar Nst })==\sqrt{\left((68-65)^{2}+(70-65)^{2}+(70-66)^{2}+(70-65)^{2}+(70-67)^{2}\right)} \\
& =\mathbf{9 , 1 6 5 2}
\end{aligned}
$$

\begin{tabular}{|c|c|c|c|c|c|c|}
\hline \multirow[t]{2}{*}{ No } & \multirow[t]{2}{*}{ Nama } & \multicolumn{3}{|c|}{ Jarak Ke Medoids } & \multirow[t]{2}{*}{ Terpendek } & \multirow{2}{*}{$\begin{array}{c}\text { Cluster } \\
\text { yang di } \\
\text { Ikuti }\end{array}$} \\
\hline & & $\mathrm{C} 1$ & $\mathrm{C} 2$ & $\mathrm{C} 3$ & & \\
\hline 1 & M. Akbar Nst & 37,2693 & 7,6158 & 9,1652 & 7,6158 & 2 \\
\hline 2 & Nurul asha Br. Sinaga & 33,6898 & 3,7417 & 12,5698 & 3,7417 & 2 \\
\hline 3 & Randi Alvino & 40,9268 & 11,0454 & 5,8310 & 5,8310 & 3 \\
\hline 4 & Syifa Amima & 38,5487 & 8,6603 & 7,6811 & 7,6811 & 3 \\
\hline 5 & Muhammad Ilham & 40,7799 & 10,8628 & 5,6569 & 5,6569 & 3 \\
\hline 6 & Fazrina kanaya & 46,1411 & 16,1245 & 0,0000 & 0,0000 & 3 \\
\hline 7 & Hanip Hasan & 24,7184 & 5,8310 & 21,5407 & 5,8310 & 2 \\
\hline 8 & Lidya Anggrainy & 30,0500 & 0,0000 & 16,1245 & 0,0000 & 2 \\
\hline 9 & Luthfi Rahman Husin & 36,3180 & 6,4807 & 9,8995 & 6,4807 & 2 \\
\hline 10 & M. Rizky Pranata & 41,7493 & 12,1655 & 6,0000 & 6,0000 & 3 \\
\hline 11 & Ramadan & 25,6320 & 4,8990 & 20,6398 & 4,8990 & 2 \\
\hline 12 & Rizky Ramadan & 35,7631 & 7,6158 & 12,1655 & 7,6158 & 2 \\
\hline 13 & Aditya & 22,8035 & 11,6190 & 25,8263 & 11,6190 & 2 \\
\hline 14 & Inayah Rizkiyah Natama Hrp & 29,0861 & 7,0000 & 19,3649 & 7,0000 & 2 \\
\hline 15 & Jumadil & 50,9117 & 21,6102 & 8,4261 & 8,4261 & 3 \\
\hline 16 & $\begin{array}{l}\text { Miftahul dina Qoyyima Butar } \\
\text { butar }\end{array}$ & 40,3237 & 11,7898 & 9,7468 & 9,7468 & 3 \\
\hline 17 & Rasyifa Musyarahmi & 15,1327 & 15,4272 & 31,3688 & 15,1327 & 1 \\
\hline 18 & Rizky Mulia Siregar & 47,9270 & 18,0555 & 3,1623 & 3,1623 & 3 \\
\hline 19 & Wakai Alfauzan & 24,7992 & 10,5830 & 24,5357 & 10,5830 & 2 \\
\hline 20 & Amando Yakub parlindungan & 32,1092 & 7,2111 & 16,7332 & 7,2111 & 2 \\
\hline 21 & M. Eriko & 49,5379 & 19,9249 & 5,9161 & 5,9161 & 3 \\
\hline 22 & Ramadhan Ichsan & 50,5371 & 21,0476 & 7,0000 & 7,0000 & 3 \\
\hline 23 & Annisa & 14,8324 & 16,1555 & 32,1092 & 14,8324 & 1 \\
\hline 24 & Mhd. Adly faturrahman & 0,0000 & 30,0500 & 46,1411 & 0,0000 & 1 \\
\hline 25 & Ririn Qurata 'Ayyum & 58,6941 & 28,7402 & 12,6491 & 12,6491 & 3 \\
\hline 26 & Suci rahmadani & 32,1714 & 4,0000 & 14,8324 & 4,0000 & 2 \\
\hline
\end{tabular}

Hasil perhitungannya secara menyeluruh seperti tabel 5 berikut:

Tabel 5. Data keseluruhan Iterasi ke-2 
JURNAL MEDIA INFORMATIKA BUDIDARMA

Volume 5, Nomor 1, Januari 2021, Page 83-89

ISSN 2614-5278 (media cetak), ISSN 2548-8368 (media online)

Available Online at https://ejurnal.stmik-budidarma.ac.id/index.php/mib

DOI 10.30865/mib.v5i1.2547

\begin{tabular}{|c|c|c|c|c|c|c|}
\hline No & Nama & & ak Ke Med & & Terpendek & Cluster \\
\hline 27 & $\begin{array}{l}\text { Alvin Aditya } \\
\text { Jumlah } \\
\text { Total Cost }\end{array}$ & $\begin{array}{c}18,2757 \\
918,7280\end{array}$ & $\begin{array}{c}14,3875 \\
332,6437 \\
1666,3406\end{array}$ & $\begin{array}{c}29,8831 \\
414,9690\end{array}$ & 14,3875 & 2 \\
\hline
\end{tabular}

c. Perhitungan total simpangan (S)

$\mathrm{S}=$ Total cost baru - Total cost lama

$=1666,3406-1576,6392$

$=89,7014$

Jika nilai $\mathrm{S}>0$ proses cluster selesai, dan didapat anggota setiap cluster.

\subsection{Pengujian}

Berikut dijelaskan Implemetasi pada tools Rapid Miner terdapat di gambar 1.

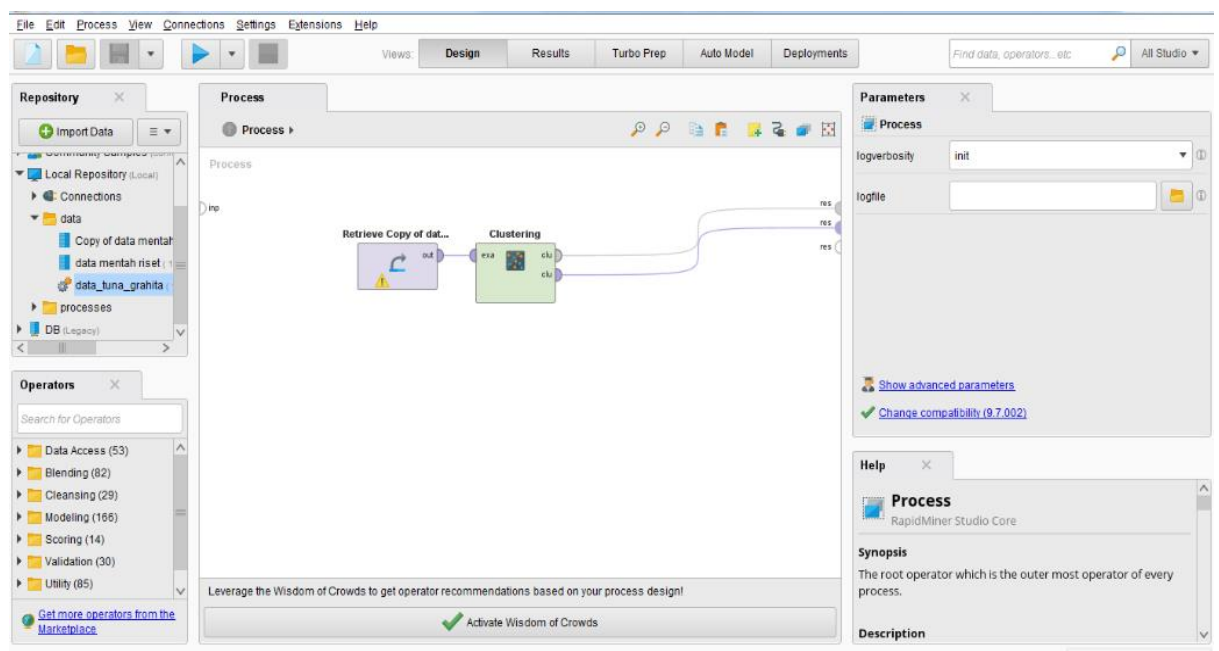

Gambar 1. Drag dan Drop Operator K-Medoids

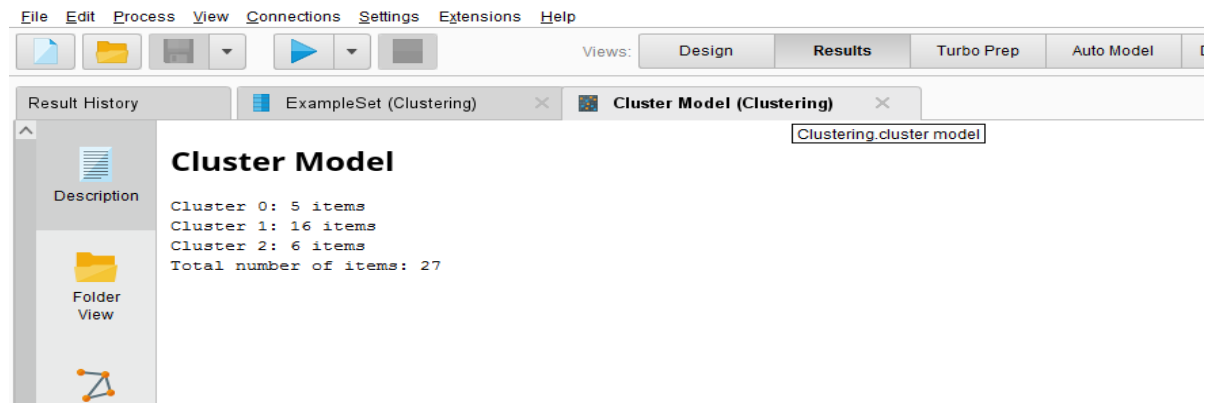

Gambar 2. Hasil Pengelompokkan Data

Dari perhitungan menggunakan tools Rapid Miner didapatkan cluster dari siwa yang totalnya 27 menghasilkan pengelompokkan ketunagrahitaan menjadi tiga bagian yaitu ringan, sedang dan berat. Pengelompokkan tersebut sesuai dengan klasifikasi yang digunakan di Indonesia saat ini dengan PP 72 Tahun 1991 yang sudah dijelasan pada uraian teori. Hasil Pengelompokkan awal berjumlah 5 siswa yang merupakan tuna grahita ringan, kedua berjumlah 16 yang merupakan tuna grahita sedang dan terakhir berjumlah 6 siswa yang merupakan tuna grahita berat.

\section{KESIMPULAN}

Kesimpulan dari penelitian ini, dimana perhitungan algoritma $K$-Medoids dengan menggunakan 5 variabel yaitu: nilai akademik, nilai kepribadian, nilai kemandirian, nilai berpikir verbal dan kecakapan/ketelitian antara perhitungan manual dengan tools menghasilkan perhitungan yang sama. Penelitian yang sudah diakukan di Sekolah Luar Biasa Muzdalifah menghasilkan pengelompokan siswa tunagrahita menjadi 3 cluster yaitu tunagrahita ringan dengan jumlah 5 siswa, tunagrahita sedang dengan jumlah 16 siswa dan tunagrahita berat dengan jumlah 6 siswa. Dengan didapatkan pengelompokkan ini semoga dapat membantu guru dan pihak sekolah dalam menyiapkan kelas dan sarana prasaran dalam belajar siswa. 
JURNAL MEDIA INFORMATIKA BUDIDARMA

Volume 5, Nomor 1, Januari 2021, Page 83-89

ISSN 2614-5278 (media cetak), ISSN 2548-8368 (media online)

Available Online at https://ejurnal.stmik-budidarma.ac.id/index.php/mib

DOI 10.30865/mib.v5i1.2547

\section{UCAPAN TERIMAKASIH}

Terima kasih disampaikan kepada Pembimbing Tesis Universitas Potensi Utama dan pihak-pihak yang telah mendukung terlaksananya penelitian ini.

\section{REFERENCES}

[1] S. Mulyati, "Penerapan Data Mining dengan Metode Clustering untuk Pengelompokan Data Pengiriman Burung," Pros. Semin. Ilm. Nas. Teknol. Komput., vol. 1, no. Senatkom, pp. 30-35, 2015.

[2] W. A. Triyanto, "ALGORITMA K-MEDOIDS UNTUK PENENTUAN STRATEGI PEMASARAN," J. SIMETRIS, vol. 6, no. 1, pp. 183-188, 2015.

[3] D. Marlina, N. F. Putri, A. Fernando, and A. Ramadhan, "Implementasi Algoritma K-Medoids dan K-Means untuk Pengelompokkan Wilayah Sebaran Cacat pada Anak," J. CoreIT, Vol.4, No.2, Desember 2018 ISSN 2460-738X ISSN 2599-3321 Implementasi, vol. 4, no. 2, p. 64, 2018, doi: 10.24014/coreit.v4i2.4498.

[4] I. B. A. Peling, I. N. Arnawan, I. P. A. Arthawan, and I. G. N. Janardana, "Implementation of Data Mining To Predict Period of Students Study Using Naive Bayes Algorithm," Int. J. Eng. Emerg. Technol., vol. 2, no. 1, p. 53, 2017, doi: 10.24843/ijeet.2017.v02.i01.p11.

[5] R. Sitanggang, T. Tulus, and Z. Situmorang, "The analysis performance method naive bayes andssvm determine pattern groups of disease," J. Phys. Conf. Ser., vol. 930, no. 1, 2017, doi: 10.1088/1742-6596/930/1/012031.

[6] M. Sadikin, R. Rosnelly, and T. S. Gunawan, "Perbandingan Tingkat Akurasi Klasifikasi Penerimaan Dosen Tetap Menggunakan Metode Naive Bayes Classifier dan C4 . 5," J. MEDIA Inform. BUDIDARMA, vol. 4, pp. 1100-1109, 2020, doi: 10.30865/mib.v4i4.2434.

[7] F. Harahap, A. Y. N. Harahap, E. Ekadiansyah, R. N. Sari, R. Adawiyah, and C. B. Harahap, "Implementation of Naïve Bayes Classification Method for Predicting Purchase," 2018 6th Int. Conf. Cyber IT Serv. Manag. CITSM 2018, no. Citsm, pp. 1-5, 2019, doi: 10.1109/CITSM.2018.8674324.

[8] Z. S. Cindy Paramitha Lubis1, Rika Rosnelly 2, Roslina3, "PENERAPAN METODE NAÏVE BAYES DAN C4.5 PADA PENERIMAAN PEGAWAI DI UNIVERSITAS POTENSI UTAMA,” CSRID J., vol. Vol. 12, pp. 51-63, 2020.

[9] Wanayumini, O. S. Sitompul, S. Suwilo, and M. Zarlis, "Supervised image classification of chaos phenomenon in cumulonimbus cloud using spectral angle mapper," Int. J. Adv. Sci. Eng. Inf. Technol., vol. 10, no. 3, pp. 987-992, 2020, doi: 10.18517/ijaseit.10.3.11493.

[10] F. Harahap, "Penerapan Data Mining dalam Memprediksi Pembelian cat," Konf. Nas. Sist. Inform., vol. 1, no. 2, pp. 102-108, 2015, doi: 10.1017/CBO9781107415324.004

[11] N. Yosiani, "RELASI KARAKTERISTIK ANAK TUNAGRAHITA DENGAN POLA TATA RUANG BELAJAR DI SEKOLAH LUAR BIASA,” vol. 1, no. 2, pp. 178-188, 2014.

[12] E. Rochyadi, "Pengantar Pendidikan Luar Biasa," File.Upi.Edu, pp. 1-54, 2012, [Online]. Available: http://file.upi.edu/Direktori/Fip/Jur._Pend._Luar_Biasa/195608181985031-Endang_Rochyadi/Modul/Pgsd4409-M6LPK.pdf.

[13] S. Suprianto, "Implementasi Algoritma Naive Bayes Untuk Menentukan Lokasi Strategis Dalam Membuka Usaha Menengah Ke Bawah di Kota Medan (Studi Kasus: Disperindag Kota Medan),” J. Sist. Komput. dan Inform., vol. 1, no. 2, p. 125, 2020, doi: 10.30865/json.v1i2.1939.

[14] Hartono, O. E., and A. D., "Determining a cluster centroid of k-means clustering using genetic algorithm," Int. J. Comput. Sci. Softw. Eng., vol. 4, no. 6, pp. 160-164, 2015.

[15] B. Riyanto, "Penerapan Algoritma K-Medoids Clustering Untuk Pengelompokkan Penyebaran Diare Di Kota Medan (Studi Kasus: Kantor Dinas Kesehatan Kota Medan)," KOMIK (Konferensi Nas. Teknol. Inf. dan Komputer), vol. 3, no. 1, pp. 562-568, 2019, doi: 10.30865/komik.v3i1.1659.

[16] A. Bhat, "K-Medoids Clustering Using Partitioning Around Medoids for Performing Face Recognition," Int. J. Soft Comput. Math. Control, vol. 3, no. 3, pp. 1-12, 2014, doi: 10.14810/ijscmc.2014.3301. 